Spring 1994

\title{
Beyond Chicago: Will Activist Antitrust Arise Again?
}

Robert H. Lande

University of Baltimore School of Law, rlande@ubalt.edu

Follow this and additional works at: http://scholarworks.law.ubalt.edu/all_fac

Part of the Antitrust and Trade Regulation Commons

\section{Recommended Citation}

Beyond Chicago: Will Activist Antitrust Arise Again?, 39 Antitrust Bull. 1 (1994)

This Article is brought to you for free and open access by the Faculty Scholarship at ScholarWorks@University of Baltimore School of Law. It has been accepted for inclusion in All Faculty Scholarship by an authorized administrator of ScholarWorks@University of Baltimore School of Law. For more information, please contact snolan@ubalt.edu. 


\section{Beyond Chicago: will activist antitrust arise again?}

BY ROBERT H. LANDE*

There is no need to document the revolution in antitrust that occurred in large part as a result of the rise of the Chicago school of antitrust and the Republicans' 1980 election victory. Now that the Democrats are back in office a natural question arises: Will there be a counterrevolution? What are the chances of significantly more aggressive antitrust in the near future?

This article will assemble a menu of relatively new ideas and circumstances that could perhaps lead to an antitrust renaissance. It will not revisit the reasons for the failures of past enforcement initiatives; ${ }^{1}$ nor will it discuss relatively "neutral" advances in the

\footnotetext{
* Associate Professor, University of Baltimore School of Law.
}

AUTHOR'S NOTE: I am grateful to Neil Averitt, Alan Fisher, James Giffin, John Kirkwood, William Kovacic, and Howard Marvel for extremely useful suggestions, and to Alexander Baehr and Jack Merritt for excellent research assistance.

1 The last time the Democrats controlled the presidency their antitrust appointees initiated or continued such doomed initiatives as no-fault monopolization, shared monopoly, and conglomerate merger cases. The author was an attorney at the Federal Trade Commission from 1978 to 
field that will not necessarily lead to a greater or lesser number of cases. ${ }^{2}$ Instead, this article will supply a list of possibilities that could conceivably contribute to an antitrust resurgence. It will begin by discussing some ideas and conditions that largely were not available to previous Democratic administrations. The article will then present many of the reasons behind antitrust's long decline. It will conclude by attempting to balance these competing tendencies to determine whether a counterrevolution is likely.

1984, and every case that he worked on there was unsuccessful. This is almost certainly not due entirely to the author's own ineptitude, and he hopes that the new enforcers will not repeat the Carter administration's mistakes. For discussions of these enforcement initiatives see Robert Pitofsky, Symposium: Anticipating Antitrust's Centennial: Comment: Antitrust in the Next 100 Years, 75 CAL. L. REv. 817, 828-29 (1987); Donald F. Turner, Symposium: Anticipating Antitrust's Centennial: Comment: Antitrust in the Next 100 Years, 75 CAL. L. Rev. 797, 807, (1987); Andrew F. Popper, The Antitrust System: An Impediment to the Development of Negotiation Models, 32 AM. U. L. REv. 283, 311 (1983).

2 Among the large number of significant advances in recent years that are not necessarily proenforcement or antienforcement are: 1 . The development of new econometric techniques for defining markets and measuring market power. See Jonathan B. Baker \& Timothy Bresnahan, Empirical Methods of Identifying and Measuring Market Power, 61 Antrrrust L.J. 3 (1992). 2. There is today a greater appreciation for innovation as opposed to static efficiency. See ANTITRUST, InNovation, and Competitiveness (Thomas A. Jorde \& David J. Teece eds., 1992. 3 . There is now a greater understanding of the motives underlying business behavior. Compare, for example, our current understanding of the procompetitive and anticompetitive effects of vertical restraints with the state of knowledge of the field in 1976. See, e.g., Alan A. Fisher et al., Do the DOJ Vertical Restraints Guidelines Provide Guidance? 32 Anttrrust Bull. 609 (1987); Impact Evaluations of Federal Trade Commission's Vertical Restraints CASEs (Ronald N. Lafferty et al., eds., Federal Trade Commission Publication 1984), reprinted in 19 Journal of REPRINTS FOR ANTITRUST LAW \& ECON. No. 2 (1989); Thomas OverstreET, Resale Price Maintenance: Economic Theories and Empirical Evidence (Federal Trade Commission Staff Report, 1983). 
I. Four relatively new ideas that could help fuel an antitrust renaissance

A new Democratic administration and plaintiffs' attorneys could search for theories that might help to revitalize antitrust. Although there is no end to possible candidates, four appear most promising. The first is the "raising someone's costs" idea. The second reinterprets the overall goals of antitrust and incorporates wealth transfer concerns (in addition to efficiency concerns). The third involves the effects of imperfect information on firm and consumer behavior. The last involves the application of strategic behavior theory to antitrust.

\section{A. The "raising someone's costs" concept}

The concept of "raising someone's costs" is an appropriate starting point because it is the most prominent of the relatively new ideas that have emerged in recent years. This article will use the term "raising someone's costs" rather than "raising rivals' costs" in order to encompass a broad cluster of related activities that sometimes can be anticompetitive. ${ }^{3}$ First, activity can be anticompetitive if it raises rivals' costs in any of a number of ways, including an increase in rivals' absolute costs, relative costs, marginal costs, fixed costs, actual costs, or potential costs. ${ }^{4} \mathrm{Sec}-$ ond, firms can raise consumers' search costs, or sellers' selling costs, in a manner that can be anticompetitive. ${ }^{5}$ Third, firms can

3 There are, of course, activities that a firm can undertake to raise others' costs, such as innovation, that are unquestionably procompetitive. See Thomas G. Krattenmaker \& Steven C. Salop, Anticompetitive Exclusion: Raising Rivals' Costs to Achieve Power Over Price, 96 YALE L.J. 209 (1986).

4 These cost increases can affect targeted rivals or entire markets. For an excellent analysis of these possibilities see John E. Lopatka, Antitrust and Professional Rules: A Framework for Analysis, 28 SAN DiEgo L. REv. 301 (1991).

5 See Detroit Auto Dealers Ass'n, 111 F.T.C. 417 (1989), aff'd in part and remanded, 955 F.2d 457 (6th Cir.), cert. denied, 113 S. Ct. 461 (1992) (Auto dealers agreed to restrict their hours of operation. This 


\section{4 : The antitrust bulletin}

raise the costs of third parties, in related markets, in an anticompetitive fashion. ${ }^{6}$

The raising someone's costs concept describes how rivals can be harmed even in the absence of traditional price predation. ${ }^{7}$ It can be applied in a variety of contexts. Not only can it affect Sherman Act section 2 monopolization cases and give standing to competitors in horizontal merger cases, but it can also affect horizontal restraint, vertical restraint and vertical merger analysis. ${ }^{8}$ It is not, of course, a totally new concept. Any boycott case, for example, can be considered as resting on a theory of raising rivals' costs. It is nevertheless an idea that was substantially developed by Dr. Steven Salop and others during the last decade. ${ }^{9}$ The idea certainly was used during the 1980s.10 Many Reagan and Bush administration antitrust enforcement officials were skeptical that these situations could ever be anticompetitive ${ }^{11}$ unless the

increased consumers' search costs and made consumers less likely to shop vigorously for the best price.).

6 See FTC v. Indiana Federation of Dentists, 476 U.S. 447 (1986). (Dentists conspired to refuse to supply xrays to insurance companies. This had the effect of making it more difficult for the insurance companies to determine that certain procedures might have been unnecessary.).

7 See Krattenmaker \&: Salop, supra note 3.

8 See id.

9 Id. See also Thomas G. Krattenmaker et al., Monopoly Power and Market Power in Antitrust Law, 76 GEO. L.J. 2412 (1987) for analysis and additional citations.

10 James Langenfeld and Louis Silvia found that the majority of Federal Trade Commission horizontal restraint cases during the 1980s can best be explained by some cost raising theory, as opposed to normal collusion or predation. They introduce the term "raising own costs" as a label for many of these cases. See James L. Langenfeld \& Louis Silvia, Federal Trade Commission Horizontal Restraint Cases: An Economic Perspective, 61 ANTITRUst L.J. 653, 655 (1993).

11 For example, the Bush administration antitrust enforcers declined to include the concept in the 1992 Federal Merger Guidelines. See 1992 U.S. Department of Justice and Federal Trade Commission Merger Guidelines, reprinted in 62 Antitrust \& Trade Reg. Rep. (BNA) (Special Supp., April 2, 1992). 
government was involved, ${ }^{12}$ however, so aggressive enforcers could utilize this framework even more in the future.

\section{B. Wealth transfers as a goal of antitrust}

A second new idea is the belief that wealth transfers are an important concern of antitrust. Before the 1980 s antitrust was generally thought to serve a variety of social, political and moral objectives. ${ }^{13}$ Part of the Chicago school revolution was to replace this belief structure with the narrow view that efficiency is the only original and legitimate concern of antitrust. ${ }^{14}$ Now a third possibility exists. ${ }^{15}$ This new approach asserts that the antitrust laws primarily were enacted to give consumers the right to purchase competitively priced goods. It condemns the use of market power artificially to raise prices and stresses that the antitrust laws were designed to prevent wealth transfers from consumers to firms with market power. Efficiency was also meant to be a concern of antitrust. But the laws' main thrust was to give consumers, not cartels or monopolies, the fruits of competitive capitalism. ${ }^{16}$

Although the wealth transfer view was rejected by most federal enforcement officials during the $1980 \mathrm{~s},{ }^{17}$ many are now starting to embrace it. This idea, moreover, has only been developed in detail with respect to certain areas of antitrust, such as in articles demonstrating that merger enforcement would be stricter under a wealth transfer approach than under an efficiency

12 There is little doubt that the government can raise industry costs in a manner that might have a disparate impact on certain firms.

13 See Robert H. Lande, The Rise and (Coming) Fall of Efficiency as the Ruler of Antitrust, 33 AntTTRust BuLL. 429, 430-31 (1988).

14 Id. at 432-34.

15 See Robert H. Lande, Wealth Transfers as the Original and Primary Concern of Antitrust: The Efficiency Interpretation Challenged, 34 Hastings L.J. 65 (1982).

16 Lande, supra note 15 , passim.

17 See Lande, supra note 13, at 458-63; id. at 438-44. 


\section{$6:$ The antitrust bulletin}

approach..$^{18}$ The concept could, however, be examined more carefully and implemented more aggressively in the future. Consideration of the transfer effects of market power (in addition to its efficiency effects) could particularly affect antitrust cases involving price discrimination (including Robinson-Patman cases and tying cases), horizontal restraint cases that involve a tradeoff between market power effects and efficiency effects, vertical restraint cases, and merger analysis. ${ }^{19}$

\section{Effects of imperfect information}

A third enforcement-oriented possibility arises from taking imperfect information concerns more seriously, pursuant to Eastman Kodak Co. v. Image Technical Services, Inc. ${ }^{20}$ This decision is so new that we cannot yet accurately predict its long-term effects on the antitrust world. We must attempt to grapple with it, however, because information issues significantly affected the Court's decision in two places, ${ }^{21}$ and were an underpinning of many of its major holdings. ${ }^{22}$

18 See Alan A. Fisher et al., Price Effects of Horizontal Mergers, 77 CAI. L. Rev. 777 (1988); Alan A. Fisher \& Robert H. Lande, Efficiency Considerations in Merger Enforcement, 71 CAL. L. REv. 1580 (1983).

19 See generally Lande, supra note 13, at 463.

$20 \quad 112$ S. Ct. 2072 (1992). This article's Kodak analysis is based upon Robert H. Lande, Chicago Takes It on the Chin: Imperfect Information Could Play a Crucial Role in the Post-Kodak World, 62 ANTrTrust L.J. 193 (1993).

21 'The first information failure involved customers' inability to predict future chances in Kodak's policy. Before 1985, potential purchasers of Kodak machines allegedly understood that after purchasing their machines they could go to an independent service organization (ISO) for parts and service. Frequently these ISOs, charged significantly less for service than did Kodak. In 1985 or 1986 Kodak changed its policy and any customer wishing to purchase Kodak's patented spare parts had to purchase a Kodak service contract as well. Kodak thus instituted an 'aftertie' between parts and service, effectively eliminating the ISOs. 
If Kodak is interpreted in a narrow fashion it is merely another important case. ${ }^{23}$ But if the decision is read very broadly, its emphasis and reliance upon imperfect information could have dramatic effects on the antitrust world, for three reasons. First, Kodak holds that anticompetitive concerns can arise despite the absence of traditional market share-based market power. ${ }^{24}$ Kodak in effect holds that there are now two ways to exploit consumers; through traditional market share-based market power, or through imperfect information. ${ }^{25}$ Imperfect information can substitute for traditional

.. Kodak's second reliance on information failures involved customers' inability to perform relatively complex life-cycle pricing comparisons. When individual consumers are involved it often is obvious that information imperfections can prevent purchasers from making optimal purchasing decisions, but a noteworthy aspect of the decision is that all of the victimized purchasers in Kodak were businesses. The Court stressed that, as a factual matter, life-cycle pricing was extremely difficult to perform accurately. Customers would have to perform this calculation for all brands on the market to be able to compare costs intelligently." See Lande, supra note 20, at 174-95 (footnotes omitted).

22 "Customers could be exploited by the aftertie only in an environment of imperfect information. Due to the 'lock-in' factor (the cost that would be incurred if a customer with a Kodak machine decided to switch to a new machine) consumers could be exploited by the aftertie. If the information possessed by customers before 1985 had been perfect, however, they would have anticipated their machines and were locked in to purchasing spare parts from Kodak. The Court said that this was an unexpected change that consumers of the machines could not reasonably have anticipated. Competition involving machines, before the machine's initial purchase, could not have protected these consumers effectively since Kodak's switch was expected by neither Kodak's customers nor its competitors. Even if a traditional structural analysis would indicate that competition in a market should protect consumers, Kodak holds that firms with small market shares can unfairly harm consumers by taking advantage of imperfect information." Id. at 194 (footnotes omitted).

23 Kodak's effects will be relatively minor if its precedent value is limited to cases involving aftermarkets, a major change in corporate policy, significant switching costs, etc.

24 See Lande, supra note 20, at 197; Kodak, 112 S. Ct. at 2087.

25 Neil Averitt verbally pointed out to the author an analogy to business torts, which also can cause harm even if they do not involve market power. 


\section{$8:$ The antitrust bulletin}

market share-based market power and can make a market that, structurally, appears competitive to behave anticompetitively. ${ }^{26}$ Second, imperfect information can create more narrowly defined relevant markets because it can effectively prevent customers from turning to certain potential substitutes. ${ }^{27}$ Consumers might not know of an option's existence or, more likely, that an option is a cost-effective substitute. If courts define markets more narrowly this usually will have the effect of making it more likely that a firm will be found to have market power. ${ }^{28}$ Third, businesses, like individual consumers, can make information-based mistakes that can allow them to be exploited. Consumer protection law's assumptions about individuals' capabilities, vulnerabilities and needs can apply to businesses as well.29

Many specific areas of antitrust law could be affected if information often is found to be significantly impaired and these imperfections are found to cause businesses to make decisions that are exploitable through the use of practices that are of antitrust concern. Among the areas that could be affected are resale price maintenance, ${ }^{30}$ exclusive dealing arrange-

26 Lande, supra note 20, at 197.

27 Even though Kodak possessed less than $25 \%$ of the photocopier market the Court focused upon the locked-in customers, of which Kodak had a $100 \%$ market share. Kodak, 112 S. Ct. at 2087.

28 For a discussion and an exception see Lande, supra note 20 , at $195 ; 197$.

29 We often assume that certain antitrust offenses are highly improbable in a market where competition is present because potential victims could simply shift to another supplier. This shift will not occur, however, if potential victims are unaware of the supracompetitive pricing and the consequent need to take defensive measures.

30 Professor Warren Grimes recently showed how retailers can use resale price maintenance to take advantage of consumers' information inadequacies in a way that causes consumers to be exploited. Resale price maintenance can be used to guarantee large retail commissions so salespeople will have an incentive to "push" certain brands of products. Grimes' model hinges on imperfect information by consumers because, if consumers knew that the only reason why sales clerks were pushing 
ments, ${ }^{31}$ tying that does not involve an aftertie, ${ }^{32}$ predatory pricing, ${ }^{33}$ and practices that potentially violate the Robinson-Patman Act. ${ }^{34}$

particular brands was so that the sales clerks would get a higher commission, the scheme would not work. Warren S. Grimes, Spit, Polish and Consumer Demand Quality: Vertical Price Restraints Revisited, 80 CAL. L. REv. 815, 834-36 (1992).

31 Dr. Gerald Brock's analysis of the Federal Trade Commission industrial gases cases involved such a situation. The industrial gases market was changing, but manufacturers realized that the change was occurring before their gas distributors realized it. The manufacturers locked their retailers in with exclusive dealing contracts. The retailers realized too late that the exclusive dealing arrangements had disadvantaged them (in a way that harmed competition). Imperfect information (an asymmetry of information because the gas producers knew more about the changing nature of industrial gases market than the retailers) explained the imposition of the tie. See Gerald Brock, Vertical Restraints in Industrial Gases, in Impact Evaluations of Federal Trade Commission Vertical Restraint Cases 386 (Ronald N. Lafferty et al., eds., FTC publication 1984) (hereinafter IMPACT Evaluations).

32 Professor Howard Marvel analyzed a technological tie between hearing aids and batteries and concluded that the purpose of the tie might well have been to impose price discrimination against heavy users of hearing aids. Consumers could theoretically have engaged in life-cycle pricing (they could have calculated the discounted present value of both the hearing aid and the batteries they were likely to buy). Because consumers were unable as a practical matter to often do this correctly, however, they could be exploited through the tie. See Marvel, Vertical Restraints in the Hearing Aids Industry in IMPACT Evaluations, supra note 31 , at $271,328-29$.

33 Predatory pricing becomes more plausible if we assume the existence of imperfect information-i.e., if we assume that even businesses can be fooled or make significant mistakes. If information is perfect, successful predation, including the necessary recoupment of short-term losses, must be extremely rare. A post-Chicago school view of the world, based upon the belief that imperfect information is more common, would conclude that predation is more common. Even old fashioned "deep pocket" predation can occur, as well as other types, such as "reputation" predation and "noisy pricing" predation. For example, if pricing and 


\section{Advances in strategic behavior theory}

The fourth possibility concerns the implications of advances in strategic behavior theory and game theory. This is a category of ideas that at its broadest includes everything this article has discussed earlier, so two additional relatively specific examples will be enough to illustrate this area's potential. ${ }^{35}$

other terms are as complex as the life-cycle pricing involved in Kodak, a firm might not realize that predatory pricing was being used against it. A firm might not take countermeasures because it believed that it was going bankrupt due to the normal workings of the marketplace. Why struggle if you believe that the would-be monopolist is more efficient? See Lande, supra note 20, at 200-01.

34 Violations of the Robinson-Patman Act require price discrimination. Before Kodak, traditionally defined market share-based market power probably was a prerequisite for illegal price discrimination. Imperfect information, however, can also permit price discrimination to occur because a firm might not know how much it actually pays for its purchases. Kodak holds that a business might not know how much it effectively pays for a product over its life cycle, and similar pricing complexities can arise after credit terms, advertising allowances, return policy, service terms, special promotions, and the like are considered. These complications also can make it especially difficult for a company to compare how much it pays with the prices that its competitors pay. Moreover, a company is more likely to provide a discount only to some of its customers when information imperfections make it less likely that other customers will discover these discounts. Thus, imperfect information could, in a Robinson-Patman setting, be a substitute for a traditional market share-based market power and provide the motive and cover for illegal price discrimination. See Lande, supra note 20, at 200-01.

35 For an excellent analysis of much of the field see Dennis A. Yao \& Susan S. DeSanti, Game Theory and the Legal Analysis of Tacit Collusion, 38 AntrTrust Bull. 113 (1993). A recent article also wonderfully illustrates how game theory and strategic interaction models can be applied in an antitrust setting. See Joseph F. Brodley \& Ching-to Albert Ma, Contract Penalties, Monopolizing Strategies, and Antitrust Policy, 45 Stan. L. REv. 1161 (1993). The authors apply a model developed by Aghion and Boulton to show how a monopolist can use a contract penalty clause as a strategic mechanism that enhances its monopoly power. "The penalty clause binds the monopolist and its customers in a coalition that wields monopoly buying power against potential entrants. The penalty forces an entrant to pay a penalty, through lower prices, in order to solicit 
The first concerns how rent-seeking behavior could lead to antitrust issues. Rent-seeking is a relatively old concept that is usually discussed by "conservative" scholars. ${ }^{36}$ But consider its application in a franchisor/franchisee context. ${ }^{37}$ Once a franchise contract is signed both parties often are locked in to some degree. Assume, consistent with Kodak, that there is imperfect information at the time of the signing of the franchise agreement and that some franchisees do not really understand what they are signing. As time passes rents might accrue due to the efforts of the franchisee-perhaps the franchise accumulates goodwill that is largely attributable to the franchisee's efforts. The franchisor could engage in rent-seeking behavior using tying arrangements or other vertical restraints to acquire this goodwill. ${ }^{38}$ Absent imperfect information this rent extraction would not be a concern for no franchisee would sign a franchise arrangement that would enable the franchisor unfairly to extract its goodwill. But if, consistent with Kodak, we posit imperfect information at the time of the franchise contracts' signing, this kind of scenario might become an antitrust concern. Could the contracts that contained the "unfair" tying arrangements or other vertical restraints constitute antitrust violations? Other restraints also could be analyzed as rent-seeking devices. ${ }^{39}$

The second example involves the use of the $5 \%$ test to help define markets. The 1984 U.S. Department of Justice Horizontal

customers from the monopolist." The authors show how this deprives the entrant of part or all of its expected return which will, in some cases, deter entry. Id. at 1163.

36 See, e.g., Richard Posner, The Social Costs of Monopoly and Regulation, 83 J. Pol. Econ. 807 (1975); Richard Posner, ANTTrRust Law: AN ECONOMIC Perspective 11-12 (1976).

37 This example is taken from Lande, supra note 20, at 200.

38 For example, a pizza franchise contract could require that pizza franchisees purchase all their supplies from the franchisor at a supracompetitive price. This could constitute effective price discrimination against successful franchisees.

39 See the discussion of exclusive dealing, supra note 31 . 


\section{2 : The antitrust bulletin}

Merger Guidelines asked whether new firms would be likely to enter a market if prices rose by a "small but significant and nontransitory" increase in price (such as $5 \%$ ). ${ }^{40}$ This standard can be criticized as being too ready to accept the possibility of entry because the potential entrants' addition of capacity to the market could depress prices, and prospective entrants would be unlikely to enter unless they were reasonably sure that prices would stay at a supracompetitive level for a long enough period for the firms to recover sunk costs. While this ambiguity was a problem in the 1984 Guidelines, the 1992 Merger Guidelines explicitly take these strategic considerations into account. ${ }^{41}$ The new formulation is accordingly more skeptical toward claims of easy entry.

\section{Changes in antitrust's overall environment that could contribute to a renaissance}

In addition to the theoretical advances discussed above, there have also been changes to antitrust's overall environment that could be conducive to a reinvigoration of the field. These new conditions include $(A)$ the reemergence of the states as aggressive enforcers, (B) increased criminal penalties, (C) narrower antitrust exemptions and, (D) increasing sophistication of plaintiffs' counsel.

\section{A. The reemergence $e^{42}$ of the states as aggressive enforcers}

The state enforcers had their most dramatic effects on the antitrust world during the $1980 \mathrm{~s}$ in the merger area, perhaps

40 U.S. Dep't of Justice, Justice Department Merger Guidelines, 49 Fed. Reg. 26,823 (1984), reprinted in 2 Trade Reg. Rep. (CCH) No. 655, กा $4490-4495$ at $\S 3.3$ (June 18,1984 ).

41 See 1992 U.S. Department of Justice and Federal Trade Commission Merger Guidelines, reprinted in 62 Antitrust \& Trade Reg. Rep. (BNA) (Special Supp., April 2, 1992).

42 "Reemergence" is a more accurate description than "emergence" because in the early years of antitrust the states often successfully challenged large national transgressors. For an excellent analysis see James 
because federal enforcement diminished considerably during this period, thus creating what many considered to be an unfortunate void. During the 1930s, 1940s and 1950s no state appears to have filed a merger case. ${ }^{43}$ Two were filed during the 1960 s and another two during the $1970 \mathrm{~s}^{44}$ During the 1980 s the states collectively or individually filed twenty-nine merger cases and another sixteen amicus briefs or interventions. ${ }^{45}$ During 1988 , moreover, the states collectively filed more merger cases than the U.S. Department of Justice's Antitrust Division. ${ }^{46}$ Many of these cases involved extremely large transactions. ${ }^{47}$ There is no reason to believe that the states will return to their former nearly dormant status in the merger area or in other areas, ${ }^{48}$ so the states' continued efforts will be a contributing factor to any coming antitrust renaissance.

May, Antitrust Practice and Procedure in the Formative Era: The Constitutional and Conceptual Reach of State Antitrust Law, 1880-1918, 135 U. PA. L. Rev. 495, 499-502 (1987). During the first 20 years of the Sherman Act the Department of Justice Antitrust Division was responsible for a total of $\$ 219,000$ in antitrust fines. Id. at 502. During this period one suit by the State of Texas alone resulted in a fine of more than $\$ 1.6$ million against the Standard Oil Co.Id.

43 See Robert H. Lande, When Should States Challenge Mergers: A Proposed Federal/State Balance, 35 N.Y. L. ScH. L. Rev. 1047 (1990).
44 Id. at $1055 \mathrm{nn} .44-45$.
45 Id. at $1056 \mathrm{nn} .46-47$.
46 Id. at $1060 \mathrm{n} .48$.

47 See, e.g., California v. American Stores, 110 S. Ct. 1853 (1990); State ex rel. Van de Camp v. Texaco, Inc., 223 Cal. Rptr. 266, 713 P.2d 1196 (Cal. 1986), aff'd, 1988-2 Trade Cas. (CCH) I 68,288, 46 Cal. 3d 1147, 252 Cal. Rptr. 221, 762 P.2d 385 (1988) (proposed Texaco-Getty merger).

48 See Richard Blumenthal et al., Antitrust Review of Mergers by State Attorneys General: The New Cops on the Beat, 67 ConN. B.J. 1, 14 (1993). 


\section{B. Increased criminal penalties}

Criminal antitrust penalties have increased in recent years. In the past, prison sentences were rarely significant, ${ }^{49}$ and were not frequent or long enough to constitute a serious deterrent against antitrust violations. There were entire years in the 1960s (and even one in the 1970s) when no one spent any time at all in prison for an antitrust offense! 50 Fines also were trivial.51 Even before the United States Sentencing Commission Guidelines went into effect on November 1, 1987, however, criminal penalties (whether measured in terms of jail time or fines) increased, as did the percentage of the Department of Justice Antitrust Division budget allocated to criminal enforcement.52 After the United States Sentencing Commission Guidelines became effective, penalties

49 There have, of course, been such exceptions as the electrical equipment conspiracy cases. See Joseph C. Gallo et al., Penalties Under the Sherman Act: A Study of Law and Economics (draft 1992).

50 Id. at $43-44$.

51 Id. at $40-41$.

52 See Charles F. Rule, Deterring Antitrust Crimes Through Stiffer Penalties, ALI-ABA Antitrust Seminar, San Francisco, CA (May 6, 1988). As Professor William Kovacic notes, "The Reagan and Bush administrations initiated unprecedented numbers of grand jury proceedings, resorted more frequently to little-used investigation techniques such as wire-tapping and electronic surveillance, broadened cooperation with other law enforcement entities and government bureaus (particularly public purchasing officials), and increasingly invoked non-antitrust statutes dealing with mail and wire fraud, false statements to government agencies, false claims for payment by the government, and perjury to prosecute apparent episodes of misconduct. . . . [In addition,] over the past decade, Congress has raised the maximum Sherman Act fine for individuals to $\$ 350,000$ and for corporations to $\$ 10$ million and has increased the maximum prison term for individuals to 3 years. Congress also established an alternative fine scheme that enables the government to collect an antitrust fine equal to double the harm suffered by victims of illegal conduct or double the gain realized by the defendant. A separate measure authorized the federal government to obtain treble damages for injuries suffered in its capacity as a purchaser." William E. Kovacic, The Identification and Proof of Horizontal Agreements Under the Antitrust Laws, 38 ANTITRUST Bull. 5, 10-12 (1993) (citations omitted). 
Beyond chicago : 15

became even more severe, ${ }^{53}$ so criminal antitrust sanctions now are more of a deterrence against anticompetitive conduct.

\section{Narrower exemptions}

Antitrust now is broader because many of its exemptions are more narrow. In 1976 the professions were practically exempt from the antitrust laws. By that year few cases in the area had been filed, ${ }^{54}$ but this "exemption" has of course greatly eroded since then. ${ }^{55}$ The state action exemption has also narrowed, ${ }^{56}$ and even the insurance exemption might be far narrower than many recently believed. ${ }^{57}$ Antitrust now reaches a greater percentage of our economy; another reason for optimism and revival.

53 Gallo et al. document an increase in penalties from 1976 through 1992 that is in many respects more than by a factor of 10 . See Gallo et al., supra note 49 , at 48-49 \& 69-70.

54 For an early example see Goldfarb v. Virginia State Bar, 421 U.S. 773 (1975) (holding that a minimum fee schedule promulgated by a professional association can violate $\S 1$ of the Sherman Act).

55 See, e.g., Joseph P. Bauer, Antitrust \& Sports: Must Competition on the Field Displace Competition in the Marketplace, 60 TENN. L. REv. 263 (1993); Neil P. Motenko, Health Care Developments, 64 AntrrRust L.J. 639 (1991); Phillip C. Kissom et al., Antitrust and Hospital Privileges; Testing the Conventional Wisdom, 70 CAI. L. REv. 595 (1982); Dennis R. Bartholomew, Antitrust and the Professions: Where Do We Go From Here?, 29 VIIL. L. Rev. 115 (1983); Phillip C. Kissom, Antitrust Law and Professional Behavior, 62 TEx. L. REv. 1 (1983).

56 1976 was, of course, before such crucial decisions as California Retail Liquor Dealers Ass'n v. Midcal Aluminum, Inc., 445 U.S. 97 (1980) (holding that immunity arises only if a state actively supervises the activity); Community Communications Co. v. City of Boulder, 455 U.S. 40 (1982) (holding that a general home rule statute does not satisfy the requirement that the delegation of power must be clearly articulated and affirmatively expressed).

57 See Hartford Fire Ins. Co. v. California, 113 S. Ct. 2891 (1993) (defendants' alleged activities held to constitute a boycott and therefore not exempt from the antitrust laws). 


\section{Increasingly sophisticated plaintiffs' lawyers}

Today plaintiff lawyers might, on the whole, be more sophisticated economically than they were a generation ago. We are all, to a large extent, only as sophisticated as we need to be. ${ }^{58}$ Before decisions like Sylvania ${ }^{59}$ in 1977 and Broadcast Music Inc. ${ }^{60}$ in 1979, plaintiff lawyers did not usually need to utilize sophisticated economic arguments. They often were not "state of the art" in this regard. But they have by now adjusted.61 There are many examples of excellent plaintiff lawyers who utilize sophisticated economic theories to achieve victories for their clients. ${ }^{62}$ Aggressive, innovative plaintiff lawyers are the necessary bridge between the theoreticians and reality. ${ }^{63}$

58 By analogy, giraffes evolved long necks to reach relatively high branches. They extended their necks only as much as was required to reach the appropriate branches. They did not evolve necks longer than those needed for survival.

59 GTE Sylvania, Inc. v. Continental T.V. Inc., 433 U.S. 36 (1977).

60 Broadcast Music, Inc. v. Columbia Broadcasting Sys., Inc., 441 U.S. 1 (1979).

61 For example, in 1982, when the Herfindahl index was introduced to the antitrust world through its inclusion in that year's Merger Guidelines, the antitrust bar was at first shocked at the prospect of having to square market shares. It quickly adjusted. After a very short period antitrust lawyers and their clients discussed Herfindahls as if they had been using them all of their lives.

62 See, e.g., Kodak, supra note 20, Hartford Fire Insurance Co., supra note 57, and Reazin v. Blue Cross \& Blue Shield, 899 F.2d 951 (10th Cir. 1990), cert. denied, 497 U.S. 1005 (1990).

63 Another example of forward-looking thinking by a sophisticated antitrust lawyer was the sponsorship by Frederick Furth (and others) of a conference designed to produce scholarship that might be helpful to those who believe in vigorous antitrust enforcement. See Eleanor M. Fox \& Robert Pitofsky, Airlie House Conference on the Antitrust Alternative: Introduction, 76 GEo. L.J. 237 (1987). 


\section{Factors that will make an antitrust renaissance less likely}

Before anyone concludes that an antitrust counterrevolution is imminent, however, a number of powerful factors must be considered. Each will make an antitrust resurgence less likely to occur. Each will tend to minimize or counteract the effects of the earlier lists of new ideas and changes in antitrust's overall environment.

First, government enforcement resources have declined significantly while the Republicans have been in office. ${ }^{64}$ For example, during fiscal year 1980 there were 1719 employees at the Federal Trade Commission. ${ }^{65}$ During fiscal year 1992 there were only $964,{ }^{66}$ and no significant increases seem likely. ${ }^{67}$ While the state antitrust enforcers have become more aggressive during this period, there are less than one hundred of them in total, and much of their time is, of necessity, consumed by relatively local pricefixing cases. They have limited time and resources for path-breaking antitrust theories or cases, and are too few in number to offset the decreases in federal enforcement resources.

Second, the federal judiciary is increasingly conservative. Professor William Kovacic notes that approximately two-thirds of federal judges are Reagan or Bush appointees, and Professor

64 Moreover, the federal govermment must of necessity spend a substantial amount of its current resources on price fixing and mergers, leaving relatively few resources for other areas.

65 See Federal Trade Commission, Fiscal Year 1994 Program Budget as Submitted to Congress, March 16, 1993, at 11.

66 Id. It seems likely, however, that the enforcers are in many ways more efficient than they were in 1980. New technology, for example, such as voice mail and PCs for almost every attorney, enables the enforcers to have a higher ratio of lawyers to secretaries. The overall downward trend presented in the text therefore probably overstates the true diminution in the enforcers' litigation capacity.

67 The current number of Federal Trade Commission employees is expected to shrink slightly. Supra note 65. 
Kovacic persuasively demonstrates that few are aggressive or liberal in their antitrust decision making. ${ }^{68} \mathrm{~A}$ surprising finding of Professor Kovacic's research, moreover, is that many judges appointed by Democrats also are quite conservative. ${ }^{69}$ There are few equivalents of a Learned Hand on the federal bench today who will readily embrace the more innovative theories discussed earlier in this article.

The third factor is the rise of the rule of reason since 1977. This has led to additional costs and delays for plaintiffs and has greatly benefited defendants. Now, for example, nonprice vertical restraints are judged under the rule of reason. ${ }^{70}$ Consider even the state of tying analysis after the Kodak decision. While this was an important plaintiff victory, the holding was in many respects narrow. ${ }^{71}$ Tying cases continue to be adjudicated under a per se standard virtually identical to the rule of reason. ${ }^{72}$ All the plaintiff in Kodak won was the right to spend years in discovery and hundreds of thousands of dollars in litigation costs to get a chance to prove a large number of difficult issues under, essentially, a rule of reason. Because rule of reason cases are more costly and time consuming, and victory is less likely than under the per se standard, fewer cases are being filed.

68 For an excellent analysis see William E. Kovacic, Judicial Appointments and the Future of Antitrust Policy, 7 ANTrTrust 8, 11 (1993) [hereinafter Judicial Appointments]; William E. Kovacic, Reagan's Judicial Appointees and Antitrust in the 1990s, 60 FordHAM L. REv. 49 (1991).

69 Kovacic, Judicial Appointments, supra note 68, at 9.

70 See Sylvania, supra note 59.

71 Kodak only directly applies to cases involving tying in aftermarkets, where the defendant made a major change in corporate policy, where information in the market is significantly impaired, and where plaintiff is locked into using defendant's products due to high switching costs. Kodak, 112 S. Ct. at 2087-88; Lande, supra note 20, at 198 n.17.

72 See Jefferson Parish Hospital District No. 2 v. Hyde, 466 U.S. 2 (1984). 
A fourth factor is the rise of international competition. ${ }^{73}$ Markets have become more international in the last 15 years as exports and imports have increased significantly. ${ }^{74}$ This means that market power is less common, markets are often defined more broadly, and entry into many markets is more likely to be judged to be easy. Although many markets were international in 1977 , this difference in degree also means there is now less need for antitrust in large sectors of the American economy.

Fifth, standing has also become tougher for plaintiffs since 1976. Brunswick Corp. v. Pueblo Bowl-O-Mat, Inc. ${ }^{75}$ and cases that followed in its wake made it more difficult for plaintiffs to show that they suffered the types of injuries that are the concern of the antitrust. ${ }^{76}$ Illinois Brick $v$. Illinois, ${ }^{77}$ moreover, which holds that only direct purchasers have standing to sue for damages, means that indirect purchasers, including most consumers, are unable to successfully receive compensation for antitrust injuries. Together these cases effectively shielded many wrongdoers and their overcharges from antitrust scrutiny.

Sixth, much of the Chicago school "new learning" is now an accepted, even core part of antitrust. ${ }^{78}$ We all now have greater

73 See, e.g., Symposium on Antitrust and International Competitiveness in the 1990s, 58 ANTTTRUST L.J. 515 (1989).

74 See National Economic Strategies for a Global Economy: Hearings Before the Senate Comm. on the Judiciary, 102d Cong., 2d Sess. 19, 21 (1992) (statement of Robert Pitofsky that imports into the United States have increased by $\$ 450$ billion since 1970).

75429 U.S. 477 (1977) (holding that to recover treble damages under $\S 4$ of the Clayton Act, a plaintiff must prove an injury that is of the type that the antitrust laws were intended to prevent, an injury flowing from that which makes the defendant's acts unlawful).

76 See, e.g., Atlantic Richfield Co. v. USA Petroleum Co., 495 U.S. 328, 334 (1990); Cargill, Inc. v. Monfort of Colorado, Inc., 479 U.S. 104, 109 (1986); J. Truett Payne Co. v. Chrysler Motors Corp., 451 U.S. 557, 562 (1981).

$77 \quad 431$ U.S. 720 (1977).

78 For an excellent analysis see William E. Kovacic, Federal Antitrust Enforcement in the Reagan Administration: Two Cheers for the Dis- 
appreciation for the needs of business and the desirability of corporate growth and efficiency. ${ }^{79}$ These relatively conservative prodefendant insights also will make a counterrevolution less likely.

Finally, there are two other aspects of antitrust that were unduly advantageous for violators in the 1970s and remain so today. First, criminal penalties are still too low. While they are significantly higher than in $1970 \mathrm{~s},{ }^{80}$ an incisive paper by Professor Joseph Gallo et al., employing a standard optimal deterrence model and reasonable assumptions ${ }^{81}$ shows that criminal antitrust penalties are even now only a fraction of those needed to obtain optimal deterrence. ${ }^{82}$ These results show that the present combination of fines and prison sentences continue to significantly underdeter antitrust crimes. ${ }^{83}$ Second, civil antitrust damages are too low, from either a deterrence or compensation prospective. ${ }^{84}$ Professor William Landes showed in 1983 that optimal antitrust damages should consist of "net harm to others," multiplied to account for detection and proof problems. ${ }^{35}$ The lack of prejudgment interest alone, however, probably lowers the nominal trebling multi-

appearance of the Large Firm Defendant in Nonmerger Cases, 12 REs. L. \& Econ. 173, 178-82 (1989), and the sources cited therein.

79 To believe today, for example, that vertical restraints are often used for procompetitive reasons does not identify one as a Chicagoist, although in 1976 it might have.

80 See the discussion supra section II(B).

81 Their assumptions include a $15 \%$ chance of detection and conviction, a $10 \%$ price markup, and that 1 year in prison is (dis)valued at $\$ 1,000,000$. See Gallo et al., supra note 49 , at 63-70.

$82 \quad I d$.

$83 I d$. They find the current penalties to be only $5 \%$ of their optimal level.

84 See Robert H. Lande, Are Antitrust "Treble" Damages Really Single Damages?, 54 Oно Sт. L.J. 115 (1993).

85 William M. Landes, Optimal Sanctions for Antitrust Violations, 50 U. CHI. L. REv. 652 (1983). 
plier down to less than the twofold level. ${ }^{86}$ When other factors, including the statute of limitations, allocative inefficiency effects of market power, uncompensated corporate time pursuing the case, and costs to the judicial system are considered, awarded antitrust damages are probably only between .5 and 1.1 times as large as actual damages. ${ }^{87}$ Because awarded damages should be significantly larger than actual damages to compensate for detection and proof problems, ${ }^{88}$ currently awarded antitrust damages are, on the average, significantly low. They are probably too low from either an optimal deterrence or a compensation perspective. ${ }^{89}$

The eight factors listed in this section help to explain why the number of antitrust cases has plummeted dramatically since the Democrats were last in office. In 1979, 1234 civil antitrust cases were filed. ${ }^{90}$ In 1992 only 502 were filed. ${ }^{91}$

\section{Conclusions}

We cannot reasonably expect a significant antitrust counterrevolution in the near future. Despite the apparent promise of the "proplaintiff" theories listed in section I, each is extremely difficult to prove and might never move from theory to commonplace reality. ${ }^{92}$ The tantalizing possibilities suggested by the factors in

\footnotetext{
86 Lande, supra note 84 , at $130-36$.

87 Id. at 159 (this range utilizes Landes' optimal deterrence framework).

ss Id. at 171.

89 Id. at $161-68$.

so Id. at $146 \mathrm{n} .148$.

91 See L. Ralph Mecham, Admin. Office of the U.S. Courts, ProCeEdings of the Judicial Conference of the United States, AnNual REPORT OF THE DIRECTOR, table C-2A, at 182 (1992).

92 For example, a court could reject the use of imperfect information to invalidate a franchise contract, suggested in note 38 , supra. The court could reason that information is always somewhat imperfect and if these clauses sometimes were invalidated, there would be insufficient business
} 
sections I and II must, moreover, be considered in light of the anti-antitrust tide outlined in section III. The net of these factors suggests that there might at most be a few areas where the number of cases will increase on the margin. Enforcers will be unlikely to specifically attempt to find, for example, a situation where vertical restraints are used to raise rivals' costs in a manner that results in an unfair wealth transfer from consumers to firms with market power. It is much more likely that they will carefully examine selected transactions and areas of the economy, especially those with heightened national interest, ${ }^{93}$ and in this way cases will arise.

Merger enforcement, for example, will not in any respect return to anything even close to a Von's Grocery ${ }^{94}$ standard.95 Nevertheless, when Kevin Arquit finished serving as Director of the Bureau of Competition of the Federal Trade Commission in 1992, he noted that he was successful in thirty-seven of thirtynine mergers that he challenged. ${ }^{96}$ When James Rill resigned as head of the Antitrust Division in 1992, he noted that he was successful in forty-five out of forty-nine merger challenges. 97 These statistics imply that if the enforcers had been willing to lower their "batting average" somewhat they perhaps could have been successful at stopping additional corporate mergers. Federal Trade Commission statistics for merger challenges made between 1987

certainty regarding the validity of franchise contracts, and that this lack of certainty could prevent people from signing franchise contracts.

93 Health care will continue to be important, for example, and the downsizing of the defense sector should also give rise to heightened interest by the enforcers in this area.

94 United States v. Von's Grocery Co., 384 U.S. 270 (1966).

95 Even if new federal enforcers desire this outcome, federal judges would not allow it to happen.

96 See Arquit to Leave FTC for New York Firm, 63 Antitrust \& Trade Reg. Rep. 507 (Nov. 22, 1992) (these figures include consent orders).

97 See [Charles] James Outlines "Good Govt Initiatives," FTC: Watch, No. 377, at 13 (Nov. 9, 1992) (these figures include consent orders). 
and 1992 also suggest that the Commission could have been somewhat more aggressive. ${ }^{98}$ Out of sixty-one challenged mergers, only one involved a Herfindahl-Hirschman index (HHI) change of less than 300 , and only three others involved an HHI change of between 300 and $400 . .^{9}$ Only one challenge was to a merger that resulted in an HHI level of less than 2000, and only seven others were to mergers that would have resulted in HHIs of less than 2500.100 These statistics suggest that more aggressive merger enforcement, challenges that often might have been upheld by the federal courts, could have been possible.

Vertical restraint enforcement could also have been somewhat more aggressive, as could Robinson-Patman Act enforcement. Good cases in these areas are extremely difficult to find, however, and it would be surprising if the new enforcers were able to find more than one or two good ones in each area per year. Section 2 of the Sherman Act could also be enforced more aggressively, but an incisive article by Professor William Kovacic persuasively shows that, with disappointingly few exceptions, the government is unable to win section 2 cases. ${ }^{101}$

98 The following statistics were cleared for release by the Federal Trade Commission's General Counsel, in aggregated form, under Commission Rule 5.12(c), 16 C.F.R. 5.12(c). The analysis and conclusions presented herein are those of the author and do not purport to represent the views of the Commission, of any individual Commissioner, or the official position of a Commission Bureau. They cover the period January 1987 through June 1992.

99 Four others also involved an HHI change of less than 500 . (Bureau of Competition estimates are used.)

100 Five others also involved a challenge to an HHI level between 2500 and 3000. (Bureau of Competition estimates are used).

101 See Kovacic, supra note 78, at 184-92; see also William E. Kovacic, Failed Expectations: The Troubled Past and Uncertain Future of the Sherman Act as a Tool for Deconcentration, 74 IowA L. REv. 1105 (1989). The government is particularly incapable of achieving significant divestiture, so the enforcers would be advised to choose $\$ 2$ cases where injunctive relief alone would be an adequate remedy. Id., especially at 1105-06. 


\section{4 : The antitrust bulletin}

Additional antitrust guidelines might be another promising project for the new antitrust enforcers. Vertical restraints guidelines that were perceived as being ideologically mainstream could certainly be useful. ${ }^{102}$ Predatory pricing could be another suitable area, as might the Robinson-Patman Act, vertical mergers, and tying.

Another possible area for change involves federal-state cooperation. Federal-state friction was high during much of the Reagan administration, but relations improved considerably during the Bush administration. ${ }^{103}$ This relationship could improve even more during a Democratic administration. There is no compelling reason why the current federal and state merger guidelines could not be combined into one mutually agreed upon document. If the state and federal enforcers continue to work together and develop mutual respect and trust, this achievement should be possible. Moreover, the federal and state enforcers might even be able to achieve a division of primary authority for merger enforcement. ${ }^{104}$ Similar federal-state cooperation could result in other jointly issued guidelines and perhaps also in jointly filed cases.

The thrust of this article has been to assemble and outline many of the significant factors that suggest that an antitrust counterrevolution could materialize, but then to sketch some of the opposing reasons and to predict that these tendencies largely will offset one another. This prediction must be tempered, however, by its uncertainty. Few antitrust analysts, for example, could have correctly predicted the Supreme Court's Kodak decision, either its

102 The Department of Justice Vertical Restraints Guidelines were believed by many not to have been an ideologically neutral document. See Fisher et al., supra note 18, at 632.

103 See Lande, supra note 43, at 1052-60; 1066-69 \& 1090-91.

104 See id. The European Community recently negotiated just such a division, determining that certain mergers should be challenged only by the Community, others only by individual nation states, and that still other mergers can be challenged at either level. Id. at 1075-80. If independent nations can work out a division of primary responsibility, our federal and state enforcers also should be able to do so. 
result or its reasoning. ${ }^{105}$ Nor is there much certainty concerning the priorities or predispositions of those who will head the antitrust enforcement agencies or will be appointed to the federal bench. Nevertheless, even an optimistic prediction suggests that the most that can be hoped for is the end of antitrust's long decline with modest increases in a few areas.

105 A comparison of two recent cases illustrates the uncertainty involved and the difficulty of making predictions in the area. Carnival Cruise Lines Inc. v. State, 111 S. Ct. 1522 (1991), written by Justice Blackmun (the author of the Kodak opinion), suggests a relatively small role for imperfect information. A clause designing the forum to be used to resolve disputes was upheld despite a lack of relevant information by plaintiffs at the time they signed the contract. By contrast, use of the expansive view of the effects of imperfect information contained in Kodak, issued only a year later, probably would have resulted in a victory for the plaintiffs in Carnival Cruise Lines. 